\title{
Incidence and cause of acute confusion in elderly patients
}

\author{
Rejeki Andayani Rahayu, R. Boedhi-Darmojo
}

\begin{abstract}
Abstrak
Konfusio akut adalah suatu problem pada lansia yang ditandai dengan penurunan derajat kesadaran yang terjadi secara tiba-tiba, sering merupakan tanda awal dari penyakit-penyakit berat yang diderita lansia, mempunyai angka kesakitan dan kematian yang tinggi dan sering mengakibatkan cacat atau imobilitas. Untuk mengetahui insidens, angka kematian, dan faktor penyebab konfusio akut, dilakukan penelitian retrospektif kepada catatan medik penderita lansia dengan konfusio akut selama 2 tahun (1998 \& 1999) yang dirawat di RSUP Dr. Kariadi Semarang (RSDK). Jumlah penderita lansia yang dirawat 5407, tetapi hanya 5191 catatan medik yang dapat dianalisa. 35\% (1838 orang, yang terdiri dari 992 pria dan 846 wanita) masuk ke rumah sakit dengan konfusio akut dan 7\% (373 orang, 197 pria dan 176 wanita) konfusio akut muncul setelah dalam perawatan. Jumlah penderita konfusio akut adalah 2211 orang (40,89\%). Angka kematian 29\% (381 pria dan 263 wanita). Tiga penyebab kematian utama adalah sepsis $(10,04 \%)$, stroke hemoragik $(5,11 \%)$ dan multifaktorial $(4,16 \%)$. Sepuluh penyakit utama yang menjadi dasar konfusio akut adalah ensefalopati hepatikum, stroke hemorrhagik, sepsis, dehidrasi sedang yang berhubungan dengan gastroenteritis, hiponatremia, infark miokard akut, pneumonia, infeksi saluran kemih, gagal jantung kongestif, dan aritmia cordis. (Med J Indones 2002; 11: 30-35)
\end{abstract}

\begin{abstract}
Acute confusion is a clinical syndrome in the elderly whose diagnosis is made by acute onset of disturbance of consciousness, impairment of cognition and fluctuating perception and has an underlying medical cause associated with usually serious medical illness. Acute confusion has a high morbidity and mortality, and patient need to stay longer in the hospital, have a higher risk for institutionalization and immobilization. The aim of this study is to recognize the incidence and most of medical illness, which cause acute confusion in elderly patients, a retrospective study based on medical record of elderly patients who were hospitalized in Dr Kariadi hospital since 1998 to 1999. 5407 elderly patients were hospitalized, but only 5191 were analyzed and included in this study. 35\% (992 men and 846 women) elderly patients had acute confusion on first arrival and $7 \%$ (197 men and 176 women) acute confusion appears in the ward. Total acute confusion was $40.89 \%$. The mortality rate was $29 \%$ (263 women and 381 men). Three most frequent cause of death were sepsis (10.04\%); hemorrhagic stroke (5.11\%); multifactor (4.16\%). Top ten diseases, which cause acute confusion, were hepatic encephalopathy, hemorrhagic stroke, sepsis, moderate dehydration due to gastroenteritis, hyponatremia, acute myocardial infarction, pneumonia, urinary tract infection, congestive heart failure, and arrhythmia cordis. (Mé́ J Indones 2002; 11: 30-35)
\end{abstract}

xeywords: acute confusional state, geriatric patients, hospital study

Curiy peoptes in Indonesia in the near future are stris:es to increase rather rapidly, so that in 2010 it's torai population will be at least similar to, or more 1 an the under five years old population. ${ }^{1}$ More wen country will be the $4^{\text {th }}$ country in the world with the largest population of elderlies. ${ }^{2}$

Acute confusion is one of the major problems found in the elderly, belonging to the so called the "geriatric giants". 3 It is caused by many diseases and

Department of Internal Medicine, Geriatric Unit, Faculty of Medicine Diponegoro University / Dr. Kariadi General Hospital, Semarang, Indonesia the main disease responsible for the syndrome are some serious illnesses that might yield a high morbidity and mortality. ${ }^{4.5}$ Data on incidence, morbidity and mortality of the cause of acute confusion in the elderly in Indonesia, at the moment are lacking, also from other developing countries.

Based on the background stated above, the aim of this study is to recognize the incidence, mortality rate and most of medical illness, which cause acute confusion in elderly patients. 


\section{METHODS}

Dr Kariadi hospital is a Government General and Academic Hostital with $>1000$ beds with an annual admission of more than 8000 patients.

A descriptive study based on medical records of elderly patients (aged $\geq 60$ ) who were hospitalized in Dr Kariadi hospital from January 1998 to December 1999 were analyzed. The diagnostic criteria of acute confusion is based on "The Confusion Assessment Method" (CAM) from Inouye et al $(1990\}^{6,7}$ and Diagnostic and Statistical Manual of Mental Disorders Method (DSM) IV criteria for delirium, ${ }^{8,9}$ as shown below:

Table 1. The Confusion Assessment Method (CAM)

\section{Acute onset and fluctuating course}

Is there evidence of an acute change in mental status from the patient's baseline?

Did this behavior fluctuate during the past day, that is, tend to come and go or increase and decrease in severity?

2. In attention

Does the patient have difficulty focusing attention, for example, being easily distractible, or have difficulty keeping track of what was being said ?

\section{Disorganized thinking}

Is the patient's speech disorganized or incoherent, such as rambling or irrelevant conversation, unclear or illogical flow of ideas, or unpredictible switching from subject to subject?

4. Altered level of Consciousness

Over all, how would you rate this patient's level of consciousness?

Alert (normal)

Vigilant (hyperalert)

Lethargic (drowsy, easily aroused)

Stuporous (difficult to arouse)

Comatose (unarouseable)

The diagnosis of delirium requires the presence/abnormal rating for criteria 1, 2 and either 3 or 4

Inouye et al ${ }^{y}$
Table 2. DSM IV Criteria for delirium

1. Disturbance of counciousness (Reduced Clarity of awareness of the environment) with reduced ability to focus, sustain, or shift attention.

2. A change in cognition (memory deficit, disorientation, language disturbance) or the development of a perceptual disturbance that is not better accounted for by preexisting, established or evolving dementoia.

3. The disturbance develops over a short period (usually hours to days) and tends to fluctuate during the course of the day.

4. There is evidence from the history, physical examination or laboratory findings, that the disturbence is caused by the direct physiological, consequences of a general medical condition.

Source: Diagnostic and Statistical Manual of Mental Disorders, $4^{\text {th }}$ ed, Washington, American Psychiatric Association Press, ${ }^{10}$

\section{RESULTS}

Five thousand, four hundred and seven (5407) elderly patients $(60+)$ were hospitalized from January 1998 to December 1999, but only 5191 medical records can be analyzed and included in this study. See further Tables 3-9 and Figure 1.

Table 3. Total elderly patients admitted in Dr. Kariadi hospital, Semarang in 1998 and 1999

\begin{tabular}{c|c|c|c|c}
\hline No & Age (yrs) & Men & Women & Total \\
\hline 1 & $60-69$ & 1826 & 1555 & 3381 \\
2 & $70-79$ & 1116 & 573 & 1689 \\
3 & $>80$ & 189 & 148 & 337 \\
\hline \multicolumn{2}{c|}{ Total } & 3131 & 2276 & 5407 \\
\hline
\end{tabular}

Total elderly patients admitted in Dr. Kariadi hospital in 1998 and 1999 were 5407 (3191 men and 2276 women).

Table 4. Elderly patients with acute confusion on first arrival

\begin{tabular}{c|c|r|c|r|c}
\hline No & Age & Men & Women & Total & $\%$ \\
\hline 1 & $60-69$ & 487 & 370 & 857 & 25.35 \\
2 & $70-79$ & 406 & 394 & 800 & 47.36 \\
3 & $>80$ & 99 & 82 & 181 & 53.71 \\
\hline \multicolumn{2}{c}{ Total } & 992 & 846 & 1838 & 33.99 \\
\hline
\end{tabular}

Elderly patients with acute confusion on first arrival were 1838 (34.0\%), 992 men and 846 women 
Table 5. Elderly patient with acute confusion which appeared and observed in the ward

\begin{tabular}{c|c|c|c|c|c}
\hline No & Age & Men & Women & Total & $\%$ \\
\hline 1 & $60-69$ & 89 & 72 & 161 & 4.76 \\
2 & $70-79$ & 67 & 67 & 134 & 7.93 \\
3 & $>80$ & 41 & 37 & 78 & 23.15 \\
\hline \multicolumn{2}{c|}{ Total } & 197 & 176 & 373 & 6.90 \\
\hline
\end{tabular}

Elderly patients which had acute confusion during admission in the ward (no confusion on first arrival) were $373(6.9 \%), 197$ men and 176 women.

Table 6. Total cases of acute confusion in Dr. Kariadi hospital

\begin{tabular}{c|c|c|c|c|c|c|c}
\hline No & Age (yrs) & Men & $\%$ & Women & $\%$ & Total & $\%$ \\
\hline 1 & $60-69$ & 576 & 31.54 & 442 & 28.42 & 1018 & 30.11 \\
2 & $70-79$ & 473 & 42.38 & 461 & 80.45 & 934 & 55.30 \\
3 & $>80$ & 140 & 74.07 & 119 & 80.40 & 259 & 76.85 \\
\hline \multicolumn{2}{r|}{ Total } & 1189 & 37.97 & 1022 & 44.90 & 2211 & 40.89 \\
\hline
\end{tabular}

Total acute confusion in the elderly patients in Dr. Kariadi hospital in 1998-1999 were 2211 (40.9\%), 1189 men and 1022 women.

Table 7. Mortality of elderly patients with acute confusion in Dr. Kariadi hospital in 1998-1999

\begin{tabular}{|c|c|c|c|c|c|c|c|c|c|}
\hline \multirow[b]{2}{*}{ No } & \multirow{2}{*}{$\begin{array}{l}\text { Age } \\
\text { (yrs) }\end{array}$} & \multicolumn{3}{|c|}{ Men } & \multicolumn{3}{|c|}{ Women } & \multirow{2}{*}{$\begin{array}{c}\text { Total } \\
\text { mortality }\end{array}$} & \multirow{2}{*}{$\begin{array}{c}\% \text { Total } \\
\text { Confusion }\end{array}$} \\
\hline & & $\begin{array}{c}\text { Total } \\
\text { mortality }\end{array}$ & $\%$ Total & $\begin{array}{c}\% \\
\text { Confusion }\end{array}$ & $\begin{array}{c}\text { Total } \\
\text { mortality }\end{array}$ & $\%$ Total & $\begin{array}{c}\% \\
\text { Confusion }\end{array}$ & & \\
\hline 1 & $60-69$ & 214 & 11,72 & 37,15 & 172 & 11.06 & 38.91 & 386 & 37.92 \\
\hline 2 & $70-79$ & 136 & 12,18 & 21,47 & 72 & 12.57 & 15.62 & 208 & 22.27 \\
\hline \multirow[t]{2}{*}{3} & $>80$ & 31 & 16,40 & 22,14 & 19 & 12.84 & 15.97 & 50 & 19.31 \\
\hline & & 381 & 12,16 & 31,46 & 263 & 11.56 & 25.73 & 644 & 29.13 \\
\hline
\end{tabular}

Total mortality in elderly male patients were 381 (31.5\%) of total acute confusion of men, and $12.2 \%$ of total elderly male patients who were hospitalized in Dr. Kariadi hospital. Total mortality in elderly female patients were $263(25.7 \%)$ of total acute confusion, and $11.6 \%$ of total elderly female patients. Total mortality in elderly patients were $644(29.1 \%)$ of total acute confusion cases. 
Table 8. Top ten diseases or syndromes associated with acute confusion

\begin{tabular}{clcc}
\hline No & \multicolumn{1}{c}{ Diseases } & Total & \multicolumn{1}{c}{$\%$} \\
\hline 1 & Hepatic Encephalopathy & 377 & 17.05 \\
2. & Hemorrhagic Stroke & 372 & 16.82 \\
3 & Sepsis & 303 & 13.70 \\
4 & Dehydration due to GE & 161 & 7.28 \\
5 & Electrolyte disturbances & 82 & 3.71 \\
\multirow{2}{*}{6} & AMI (Acute Myocardial & 76 & 3.44 \\
7 & Infarction) & 72 & 3.26 \\
8 & Pneumonia/Bronchopneumonia & 71 & 3.21 \\
9 & CHF (Congestive Heart Failure) & 67 & 3.03 \\
10 & Multifactor /mixture & 214 & 9.68 \\
\hline \multirow{2}{*}{ Total } & 1795 & 81.18 \\
\hline
\end{tabular}

Hepatic encephalopaty, hemorrhagic stroke, and sepsis were the leading cause of acute confusion, especially hepatic encephalopathy which appeared during admission in the ward $(41 \%)$ and then followed by sepsis $(22 \%)$. Hemorrhagic stroke was the main cause of acute confusion on first arrival (39\%) and followed by dehydration and electrolyte* disturbances (19\% and 18\%).

Table 9. Three most frequent cause of death in this study

\begin{tabular}{clcl}
\hline No & \multicolumn{1}{c}{ Diseases } & Men & Women \\
\hline 1 & Sepsis & 222 & 34.47 \\
2 & Hemorrhagic Stroke & 113 & 17.55 \\
3 & Multifactor & 92 & 14.29 \\
\hline & Total & 427 & 66.30 \\
\hline
\end{tabular}

Like in the younger patients, sepsis is still the main cause of death in the delirious elderly patients

\section{DISCUSSION}

Epidemiological research before the last decade or so was seriously impaired by differences in study population and the absence of clear, operationalized criteria. DSM-IV has provided suitable criteria so that cross study comparison are now being made. Other issues include (1) the absence of reliable and valid research instruments, (2) case finding methods, (3) study populations, (4) co-morbidity, especially with dementing illnesses. It is not surprising that for medical inpatient units, prevalence estimates vary from 10 to $30 \%$ and incidence estimates vary even more at 4 to $53 \%{ }^{8}$

In our study incidence of acute confusion was $40.9 \%$, among which $34.0 \%$ were found on first arrival and $6.9 \%$ acute confusion appeared later in the ward. Considering that this study is a hospital study, a selected group of patients and not a community study, that explains why the incidence is higher compared with other data from many community studies as reported below.

In recent years, the data of acute incidence of confusion among the community dwelling older people in the of USA has been reported to range 5 $10 \%$ of those above age 65 and close to $20 \%$ of those over $75 .^{4}$ In nursing homes in the USA 50 to $80 \%$ of those above age 65 have some degree of cognitive impairment. ${ }^{4}$ One-third to half of elderly patients admitted to acute medical care and surgical services also exhibit a varying degree of confusion. ${ }^{4}$

Other data showed that since 1990, several prospective studies based on DSM-III and DSM-III-R have demonstrated that, at the time of hospital admission, between $10 \%$ and $15 \%$ of older medical patients meet the criteria for delirium. ${ }^{5}$ Of those admitted without delirium, an additional of 5\% to $30 \%$ might subsequently develop the disorder. ${ }^{5}$ A meta analysis from eight recent studies reported a one months mortality of $14 \%$ and a six months mortality of $22 \%$ following a diagnosis of delirium (controls showed mortality rates of $5 \%$ and $10 \%$ at one and six months, respectively). ${ }^{12}$ Prevalence of acute confussion in an Australian hospital was $29 \% .{ }^{13}$ Other epidemiology data from Australia showed that delirium affects 14$56 \%$ of hospitalised patients with a further $30 \%$ of patients having evidence of a 'partial syndrome' (exhibiting some features of delirium, without fulfilling the DSM-IV criteria for diagnosis). The average age of patiens developing delirium is 75 years old, with only a moderate proportion of patients affected on admission to hospital, and many more developing signs three or more days after admission or surgery. Levkoff et al., in a study of 325 elderly patients admitted to a teaching hospital, reported that only $10 \%$ had delirium at admission, while a further $31 \%$ developed it during their hospitalization. ${ }^{14}$

Mortality rate of acute confusion patients in our study was $29.1 \%$, with various causes of death and 
different range of days, varying from 7 to 28 days. The three most frequent underlying cause of death were sepsis, hemorrhagic stroke, and multifactors respectively. A meta-analysis from 8 recent studies reported a 1 month mortality of $14 \%$ and a 6 months mortality of $22 \%$ following a diagnosis of delirium (controls showed mortality rates of $5 \%$ and $10 \%$ at 1 and 6 months, respectively). ${ }^{12}$

In our study, the result showed that the total incidence of acute confusion (delirium) was $40.9 \%$, on first arrival being $33.9 \%$, in the ward being $6.9 \%$, while the one-month mortality rate was $29.1 \%$. It is higher than the above data from the USA, except for the mortality with incidence of delirium which appeared in the ward. It could be due to more serious illness and late admission in the hospital.

Various underlying causes of delirium in geriatric patients were metabolic disorders (eletrolyte abnormalities, acid base disturbance, hypoxia, etc), infections, decreased cardiac output (dehydration, acute blood loss, acute myocardial infarction, congestive heart failure), stroke, drugs, intoxication, acute psychosis, and others (hypo-hyperthermia, fecal impaction, urine retention, etc). ${ }^{4,15,16}$

The data about top 10 diseases or syndromes associated with acute confusion in this study (Table 8 ) resembled the common causes reported elsewhere. In addition, in this study a multifactor/mixture of causes were found in higher degree $(9.7 \%)$. This data indicate that the elderly people who arrived in Dr. Kariadi hospital have already complicated illness and were in a more serious condition.

\section{CONCLUSIONS}

1. The incidence of acute confusion in the elderly patients in Dr. Kariadi hospital, Semarang could be observed in $40.87 \%$. Total incidence in male patients was more frequent than in female patients, except at the age of 70 or more where the incidence in women was higher.

2. Disease associated with acute confusion found in this study were hepatic encephalopathy, hemorrhagic stroke, sepsis, dehydration due to GE, electrolyte disturbances, AMI (Acute Myocardial Infarction), pneumonia/bronchopneumonia, urinary tract infection, CHF (Congestive Heart Failure), and multifactor/mixture.

3. The hospital mortality rate of acute confusion in Dr. Kariadi Hospital Semarang was 29.13\%, with sepsis as the main cause of death.

4. The three major causes leading to acute confusion were hepatic encephalopathy, hemorrhagic stroke, and sepsis.

Finally, other studies of this kind in hospitals as well as in the community are needed to complete the epidemiological data and moreover, to make us more alert to anticipate this serious problem.

\section{REFERENCES}

1. Hadi-Martono. Gangguan kesadaran dan kognitif pada usia lanjut. Dalam: Boedhi-Darmojo, Hadi-Martono (editor). Buku Ajar Geriatri. Jakarta, Balai penerbit FKUI; 1999.p.152-76.

2. Boedhi-Darmojo. Demografi dan epidemiologi populasi lanjut usia. Dalam: Boedhi-Darmojo, Hadi-Martono (editor). Buku Ajar Geriatri. Jakarta, Balai penerbit FKUI; 1999.p.35-55.

3. Brocklehurst JC, Allen SC. Geriatrics medicine for student. London, Churchill Livingstone, 1987.p.61-72.

4. Kane RL, Ouslander JG, Abrass IB. Essentials of clinical geriatrics, $4^{\text {th }}$ ed. New York, Mc Graw-Hill, Inc; 1999.p.125-57.

5. Reuben DB, Yoshikawa TT, Besdine RW. Geriatrics review silabus, a core curriculum in geriatric medicine. New York, American Geriatric Society; 1996.p.120-3.

6. Reichel W, Rabins PV. Evaluation and management of the confuse, disoriented or demented elderly patient. In: Reichel W ed: Care of the elderly, clinical aspect of ageing, 4th ed. Baltimore, Williams and Wilkins; 1995.p. 142-53.

7. Lipstzin B et al. An empiric study of diagnostic criteria for delirium, Am J Psychiatry, 1991:148-54.

8. Tune LE. Delirium. In: Hazzard WR, Blass JP, Ettinger WP et al ed. Principles of geriatric medicine and gerontology, $4^{\text {th }}$ ed. New York, Mc Graw-Hill, Inc; 1999. p. $1229-37$.

9. Inouye $\mathrm{S} \mathbf{K}$ et al. Clarifying confusion: the confusion assessment method. A new method for detection of delirium. Ann Intern Med, 1990; 113: 941-8.

10. Diagnostic and statistical manual of mental disorders, $4^{\text {th }}$ ed, Washington, American Psychiatric Association Press, 1994.

11. Huma AL, Owens NJ. Drugs and the elderly. In: Reichel $\mathrm{W}$ ed. Care of the elderly, clinical aspect of ageing, 4th ed. Baltimore, Williams and Wilkins; 1995.p.41-63.

12. Trzepacz P, Norton J. Altered mental status. In: Hazzard WR, Blass JP, Ettinger WP et al ed, Principles of geriatric medicine and gerontology, $4^{\text {th }}$ ed. New York, Mc GrawHill, Inc; 1999.p.1403-12. 
13. Nair B, O'Dea I, Lim L, Thakkinstian A. Prevalence of geriatric syndromes in a tertiary hospital. Australian Journal on Ageing, 2000; $19: 81-90$.

14. Moran JA, Dorevitch MI. Delirium in the hospitalised elderly. The Australian Joumal of Hospital Pharmacy, $2001 ; 31: 35$.
15. Callaghan JD, Katz B. Case report: Adverse drug reactions mimicking disease. Australian Journal on Ageing, $1999 ; 18: 198-200$

16. Snowdown J. Management of late-life depression. Australian Journal on Ageing, 1998; 17 : 57-62. 